PRAKTYCZNE PROBLEMY ADMINISTRACYJNO-PRAWNE REGULACJE ZAPEWNIENIA PRAW PACJENTA ZAKLADU PSYCHIATRYCZNEGO I SPOSOBY ICH ROZWIAZZYWANIA

\author{
Serhii Hvozdyk \\ student \\ Prywatnej Spótki Akcyjnej ,,Uczelnia „,Międzyregionalna Akademia Zarządzania Personelem” \\ (Kijów, Ukraina) \\ ORCID ID: 0000-0002-4355-5060 \\ Hvozdyk@gmail.com
}

\begin{abstract}
Adnotacja. Znaczenie tego artykułu polega na tym, że określenie praktycznych problemów administracyjno-prawnych regulacji zapewnienia praw pacjentów zakładów psychiatrycznych pomoże poprawić wykonywanie obowiązków i zadań przez przedstawicieli prawnych, władze publiczne i pracowników zakładów psychiatrycznych w zakresie pomocy w realizacji przez pacjentów ich praw, tworząc dla nich komfortowe warunki leczenia. Proponowane rozwiązania powinny mieć na celu stworzenie jednolitego i skuteczniejszego mechanizmu zabezpieczenia, a tym samym wyeliminowanie kolizyjności przepisów ustawowych. W artykule przeanalizowano rodzaje praktycznych problemów administracyjno-prawnych regulacji zapewnienia praw pacjenta zakładu psychiatrycznego. Wyjaśniono treść każdego z takich problemów. Wskazano na braki i luki w prawie administracyjnym w badanym zakresie. Stwierdzono, że problemy w regulacji administracyjno-prawnej zapewniania praw pacjentów zakładów psychiatrycznych są spowodowane niewystarczającą uwagą na podniesienie poziomu świadomości prawnej pracowników zakładów psychiatrycznych i poziomu edukacji prawnej pacjentów zakładów psychiatrycznych i ich przedstawicieli prawnych. Innym powodem, który warunkuje obecność problemów, jest niewystarczająca szczegółowość procedury administracyjnej w celu zapewnienia zasad świadczenia opieki psychiatrycznej, ustalonej przez prawo miedzynarodowe, w wyniku czego ich przestrzeganie w praktyce jest cześciowe i dobrowolne.

Słowa kluczowe: problemy, prawo administracyjne, regulacje administracyjno-prawne, zabezpieczenie praw pacjenta, zakład psychiatryczny.
\end{abstract}

\title{
PRACTICAL PROBLEMS OF ADMINISTRATIVE AND LEGAL REGULATION OF ENSURING THE RIGHTS OF THE PATIENT OF THE PSYCHIATRIC INSTITUTION AND WAYS OF THE SOLUTION
}

\author{
Serhii Gvozdyk \\ Applicant \\ Interregional Academy of Personnel Management (Kyiv, Ukraine) \\ ORCID ID: 0000-0002-4355-5060 \\ Hvozdyk@gmail.com
}

\begin{abstract}
The relevance of the article is that identifying practical problems of administrative and legal regulation of the rights of patients in psychiatric institutions will help to improve the performance of duties and tasks by legal representatives, public authorities and employees of psychiatric institutions to help patients exercise their rights, create comfortable treatment conditions. The proposed solutions should be aimed at creating a single and more effective enforcement mechanism, and therefore will eliminate the conflict of laws. The article analyzes the types of practical problems of administrative and legal regulation of ensuring the rights of patients of a psychiatric institution. The content of each of these problems is clarified. The shortcomings and gaps of the administrative legislation in the researched sphere are pointed out. It is concluded that the problems in the administrative and legal regulation of ensuring the rights of patients in psychiatric institutions are caused by insufficient attention to raising the level of legal awareness of employees of psychiatric institutions and the level of legal education for patients of psychiatric institutions and their legal representatives. Another reason for the problems is the insufficient detail of the administrative procedure for ensuring the principles of psychiatric care established by international law, as a result of which their observance in practice is partial and voluntary.

Key words: problems, administrative legislation, administrative and legal regulation, ensuring the rights of the patient, psychiatric institution.
\end{abstract}

\section{ПРАКТИЧНІ ПРОБЛЕМИ АДМІНІСТРАТИВНО-ПРАВОВОГО РЕГУЛЮВАННЯ ЗАБЕЗПЕЧЕННЯ ПРАВ ПАЦІНТА ПСИХІАТРИЧНОГО ЗАКЛАДУ ТА ШЛЯХИ ЇХ ВИРІШЕННЯ}

\author{
Сергій Гвоздик \\ здобувач \\ ПрАТ «ВНЗ «Міжрегіональна Академія управління персоналом» (Київ, Україна) \\ ORCID ID: 0000-0002-4355-5060 \\ Hvozdyk@gmail.com
}

Анотація. Актуальність статті полягає в тому, що виявлення практичних проблем адміністративно-правового
регулювання забезпечення прав пацієнтів психіатричних закладів допоможе покращити виконання обов'язків 
та завдань законними представниками, органами публічної влади та працівниками психіатричних закладів щодо допомоги у реалізації пацієнтами своїх прав, створення їм комфортних умов лікування. Запропоновані шляхи вирішення мають бути спрямовані на створення єдиного та більш ефективного механізму забезпечення, а отже, виключатимуть колізійність законодавчих приписів. У статті проаналізовано види практичних проблем адміністративно-правового регулювання забезпечення прав пацієнта психіатричного закладу. 3’ясовано зміст кожної is таких проблем. Вказано на недоліки та прогалини адміністративного законодавства у досліджуваній сфері. Зроблено висновок, що проблеми в адміністративно-правовому регулюванні забезпечення прав пацієнтів психіатричних закладів викликані недостатньою увагою до підвищення рівня правосвідомості працівників психіатричних закладів та рівня правової освіти для пацієнтів психіатричних закладів та їхніх законних представників. Ще однією причиною, що зумовлює наявність проблем, є недостатня деталізація адміністративного порядку забезпечення принципів надання психіатричної допомоги, що встановлені міжнародним законодавством, унаслідок чого їх дотримання на практиці є частковим та добровільним.

Ключові слова: проблеми, адміністративне законодавство, адміністративно-правове регулювання, забезпечення прав пацієнта, психіатричний заклад.

Вступ. Виявлення практичних проблем адміністративно-правового регулювання забезпечення прав пацієнтів психіатричних закладів допоможе покращити виконання обов'язків та завдань законними представниками, органами публічної влади та працівниками психіатричних закладів щодо допомоги у реалізації пацієнтами своїх прав, створення їм комфортних умов лікування. Запропоновані шляхи вирішення мають бути спрямовані на створення єдиного та більш ефективного механізму забезпечення, а отже, виключатимуть колізійність законодавчих приписів. Необхідним є використання наукових концепцій, теорій та європейських стандартів під час виявлення шляхів вирішення практичних проблем.

Варто вказати, що проблеми практичного характеру щодо адміністративно-правового регулювання забезпечення прав пацієнтів попередньо досліджувалися лише частково щодо психіатричної й медичної допомоги, охорони здоров’я, цивільних правовідносин та кримінального покарання такими вченими, як: А.Я. Берш, Т.Ю. Вислоцька, Т.В. Войчук, О.Г. Данильян, Г.В. Іванцова, А.П. Казмірчук, Д.Й. Клапатий, Ю.А. Козаченко, Н.В. Коляденко, І.М. Льовків, О.В. Негодченко, А.І. Олійник, Н.М. Опольська, А.В. Семенова, І.Я. Сенюта, А.В. Сибірний, О.О. Стулов, Г.М. Устінова-Бойченко, Т.Г. Фоміна, Д.А. Чернушенко.

Основна частина. Проблеми адміністративно-правового регулювання забезпечення прав пацієнтів психіатричних закладів висвітлені як у наукових працях, так і у дослідженнях міжнародних організацій. Так, учені Кентського університету, досліджуючи ситуацію із психічним здоров'ям в Україні, вказують на проблему застосування «примусу для надання психіатричної допомоги», задля вирішення якої необхідно «прийняти державну політику щодо зменшення примусових послуг та поступово усунути таку практику загалом. Крім того, має бути підвищено зв'язок між громадою та лікарнями, підвищено правову підготовку персоналу та користувачів психіатричної допомоги» (Mapping \& understanding exclusion in Europe). Проблема примусовості надання психіатричної допомоги безпосередньо пов'язана з існуванням та дієвістю контролю за діяльністю психіатричних закладів, відносин між органами опіки та піклування й законними представниками. Психіатрична допомога у примусовому порядку має застосовуватися лише у випадках неможливості надати допомогу в добровільному порядку, гарантіями чого мають бути колективні рішення лікарів-психіатрів, можливість залучення незалежних психіатрів, перевірка правомірності прийнятого рішення як судом, так і органами виконавчої влади. Разом із тим застосування запропонованих напрямів вирішення проблеми буде спірним в Україні, оскільки права на підвищення кваліфікації, отримання правових знань та добровільність психіатричної допомоги мають бути не лише визнані, що, власне, уже зроблено в національному законодавстві, але й створені спеціальні механізми щодо таємниці лікування, надання державної допомоги, створення спеціальних курсів та закріплення обов'язків з підвищення саме правових знань працівників психіатричних закладів за Міністерством охорони здоров’я та його територіальними органами.

Створюючи Концепцію розвитку охорони психічного здоров'я в Україні на період до 2030 року, було визначено перелік проблем у сфері надання психіатричної допомоги, забезпечення прав пацієнтів психіатричних закладів стосуються такі: «не передбачення системи профілактики психічного здоров'я; недосконале регулювання дій щодо охорони психічного здоров'я; кадрове забезпечення психологами, психіатрами, соціальними працівниками перебуває на низькому рівні; знижена доступність психіатричної допомоги; зосередження центрів психіатричної допомоги у спеціалізованих закладах охорони здоров’я та інтернатних закладах; невикористання новітніх технологій; адміністрування та моніторинг щодо охорони психічного здоров'я відсутні, а координація органів державної влади є недостатньою» (Про схвалення Концепції розвитку охорони психічного здоров’я в Україні на період до 2030 року, 2018). Проблему кадрового забезпечення можливо розглядати як відсутність спеціальних державних тренінгів та семінарів для психіатрів, так і недостатність контролю за якістю медичної освіти, ії відповідності міжнародним стандартам. Можливість набути практичні знання отримується лише під час роботи із психіатрами з тривалим професійним досвідом. Оскільки за часів СРСР приватна психіатрична допомога була забороненою, то висококваліфіковані психіатри працювали в психіатричних закладах. Надалі це й спричинило створення центрів надання психіатричної допомоги лише у спеціалізованих закладах охорони здоров’я. Способом вирішення такої проблеми є забезпечення державного заохочення приватної діяльності психіатрів, створення програм їх фінансування. Це вплине і на підвищення звернень за допомогою. Так, проблема низької доступності психіатричної допомоги пов’язана із порядком іiі надання, який обов'язково передбачає включення інформації про психічний розлад до медичної історії хвороби. Надалі така інформація може стати перешкодою для отримання роботи, 
спеціальних прав або ж зашкодити репутації особи, оскільки незалежно від характеру психічного розладу, його небезпеки для оточуючих, доступність інформації про звернення за психіатричною допомогою розглядатиметься як привід для стигматизації.

О.О. Стулов звертає увагу на потребу законодавчого врегулювання «порядку та місця лікування хворих на тяжкі психічні розлади, що були засуджені до довічного позбавлення волі, та звільнення яких через хворобу (ст. 84 КК України) буде проблемним» (Стулов, 2013: 99). Сутністю такої проблеми є з'ясування потреби у продовженні відбування покарання після видужання особи, оскільки кримінальне законодавство визначає як можливість звільнення на піклування родичам чи опікунам, так і можливість подальшого відбування покарання. Оскільки між заходами примусового медичного характеру та видами злочинів і їх покаранням безпосереднього зв'язку на рівні законодавства не встановлено, то виникає й питання щодо виду утримання пацієнтів. Так, застосування госпіталізації до закладу з надання психіатричної допомоги зі звичайним наглядом може становити загрозу для інших пацієнтів психіатричного закладу та збільшуватиме ймовірність втечі. Водночас госпіталізація із суворим наглядом може суперечити цілям лікування, особливо тяжких психічних розладів. Тобто адміністративно-правове регулювання забезпечення прав пацієнтів психіатричних закладів повинне стосуватися більш чіткого визначення відповідності між видом кримінального правопорушення, його покаранням та видом примусових заходів медичного характеру, а також ефективністю лікування пацієнта незалежно від вчинення правопорушення. Це можливо зробити завдяки зміні критеріїв вибору виду примусових заходів у кримінальному та кримінально-процесуальному законодавстві разом із деталізацією на підзаконному рівні порядку лікування і взаємодії між правоохоронними органами й психіатричними закладами.

Досліджуючи тему забезпечення прав людини щодо охорони психічного здоров'я, Д.А. Чернушенко до проблем зараховує такі: «низький рівень сформованості системи державних органів та організацій щодо забезпечення медичних прав; недостатність фінансування медичної сфери загалом; низьку кваліфікацію та рівень етичної поведінки, збільшення впливу людського фактора. Усе це $\epsilon$ наслідком проблеми, залишеної у спадок СРСР, - державні органи щодо захисту та гарантування прав людини, у тому числі тієї, яка хворіє на психічні розлади, захищають та гарантують дію системи, а не права пацієнтів» (Чернушенко, 2013: 178). Відповідно, проблеми забезпечення прав пацієнтів психіатричних закладів викликані історичними, економічними, правовими та психологічними чинниками. Це свідчить про недостатню дію правових принципів у відносинах щодо надання й отримання психіатричної допомоги, що, своєю чергою, пов'язано iз нерозумінням їх змісту, значенням та відсутністю адміністративно-правових засобів заохочення чи примусу до дотримання таких принципів. Щодо спеціалізованих органів, то управління та контроль за діяльністю щодо надання психіатричної допомоги проводиться Міністерством охорони здоров’я. Проте зрозумілим є залучення Міністерства соціальної політики у питаннях соціального захисту, соціальної матеріальної допомоги та роботи соціальних служб, а також правоохоронних органів щодо лікування психічних розладів в осіб, які вчинили кримінальні правопорушення. Проблемною є координація їхньої діяльності, що допоможе формувати спільні пропозиції до бюджету, а отже, й збільшити фінансування. Разом із тим на існування проблем адміністративно-правового регулювання забезпечення прав пацієнтів психіатричних закладів опосередковано впливають і загальні проблеми щодо поширення корупції в органах державної влади, низького контролю за використанням бюджету.

Учасники асоціації психіатрів України зауважують, що в психіатричних закладах є проблема щодо «доступу до них для пацієнтів, адже лікарні знаходяться далеко від великих міст та до них складно дістатися. Тобто пацієнти психіатричних закладів ізольовані від своїх родин, а контакт із світом є складним. Доступ до пацієнтів передбачає обтяжливі процедури щодо вступу й виписки, стигматизацію через перебування у такій установі» (Організація служб охорони психічного здоров'я, 2017: 35). Вирішення такої проблеми полягає у забезпеченні приватності відвідувань, спрощення такої процедури для близьких осіб та законних представників, а також відшкодуванням коштів, витрачених на дорогу. Також необхідним є технічне забезпечення психіатричних закладів щодо використання Інтернету, мобільних телефонів чи інших пристроїв задля підвищення соціальності пацієнтів та зменшення наступного стресу, пов'язаного із випискою 3 лікарні та потребою самостійно перебувати в суспільстві.

А.П. Казмірчук наголошує на потребі організації отримання психіатричної допомоги особам, що «беруть участь у локальних збройних конфліктах. В останні десятиліття кількість таких осіб зросла, а також змінився і порядок формування психіатричного профілю щодо збільшення психічних розладів. Це спричиняє потребу у внесенні коректив до організації надання психіатричної допомоги та підготовки кадрів» (Казмірчук, Іванцова, Льовків, 2017: 18). Проблемним аспектом є відсутність законодавчого порядку надання психіатричної допомоги для військових службовців як обов'язку таких військовослужбовців її прийняти та обов'язку в психіатрів іiі надати одразу після повернення з центру бойових дій. Застосування принципу добровільності у цьому разі є недопустимим через наявність факту стигматизації у суспільстві осіб, що звертаються за психіатричною допомогою, та спеціальний правовий статус військовослужбовця. Важливо, щоб процес надання психіатричної допомоги не був формальним та не здійснювався виключно для отримання дозволу/ довідки чи іншого документа, що підтверджує психічне здоров’я. Тому слід гарантувати таємницю результатів спілкування між психіатром та військовим. 3 огляду на особливості професійної діяльності обов' язковим $\epsilon$ проведення спеціального навчання психіатрів та створення окремих порядків лікування військових осіб залежно від психічного розладу. 
Дослідження Клайва М'ю свідчить, що під час діяльності психіатричних закладів проблемою є «наявність «де-факто недобровільних пацієнтів», адже вони не надавали згоду на перебування у такому закладі або вона не була усвідомленою й добровільною. Це стосується осіб, які бажають відкликати свою згоду на госпіталізацію, адже їхня думка просто ігнорується або буде розпочинатися процедура примусової госпіталізації.Найбільша небезпека полягає у тому, що для осіб, які де-юре надали добровільну згоду, не створено окремих юридичних гарантій чи заходів забезпечення їхніх прав» (Клайв, Гнатовський, 2019: 57). Ця проблема неодноразово розглядалася як науковцями, так і у рішеннях КСУ та ЄСПЛ. Примусова госпіталізація допускається зі згоди законного представника та органу опіки й піклування, однак передбачає подальше звернення до суду. Коли ж добровільність згоди особи з психічними розладами допомагає уникнути потреби судового розгляду, зрозумілою $є$ неможливість постійного контролю прийому всіх пацієнтів 3 боку суду. Задля зменшення ризиків неправомірного утримання необхідно запровадити електронні автоматизовані системи прийому до психіатричного закладу й аналогічний порядок відкликання згоди, що унеможливлює ігнорування з боку лікарів такого прохання пацієнта. Ініціювання відкликання добровільної згоди має проходити із залученням незалежного психіатра та неможливістю створити перешкоди для реалізації такого права пацієнтом працівниками психіатричного закладу.

Отже, на основі проведеного дослідження можна дійти висновку, що адміністративно-правове регулювання забезпечення прав пацієнтів психіатричних закладів має значну кількість проблемних аспектів, що впливають як на отримання психіатричної допомоги, так і на реалізацію інших природних прав пацієнтів.

Практичні проблеми адміністративно-правового регулювання забезпечення впливають на сучасний стан прав пацієнтів психіатричних закладів та потребують негайного вирішення для усунення перешкод у реалізації таких прав та попередження правопорушень, викликаних недосконалим законодавчим регламентуванням. Так, до проблем адміністративно-правового регулювання забезпечення прав пацієнтів психіатричних закладів можна віднести:

1) згода суду для застосування примусу до недієздатних осіб законодавчо не передбачена;

2) право на таємницю надання психіатричної допомоги пацієнтам психіатричного закладу порушується в процесі підтвердження, забезпечення та реалізації такої допомоги;

3) право пацієнтів психіатричних закладів на залучення незалежного лікаря-психіатра є обмеженим.

Висновки. Отже, на основі проведеного дослідження можна зрозуміти, що проблеми в адміністративно-правовому регулюванні забезпечення прав пацієнтів психіатричних закладів викликані недостатньою увагою до підвищення рівня правосвідомості працівників психіатричних закладів та рівня правової освіти для пацієнтів психіатричних закладів і їхніх законних представників. Ще однією причиною, що зумовлює наявність проблем, є недостатня деталізація адміністративного порядку забезпечення принципів надання психіатричної допомоги, що встановлені міжнародним законодавством, унаслідок чого їх дотримання на практиці є частковим та добровільним. Аналіз чинного законодавства свідчить про використання застарілих підходів до адміністративно-правового регулювання щодо незбалансованості застосування імперативного методу й рекомендаційних та заохочувальних способів впливу на забезпечення прав пацієнтів психіатричних закладів. Водночас запропоновані шляхи вдосконалення чинного законодавства спрямовані на комплексне подолання як теоретичних, так і практичних проблем, що дозволить створити ефективний механізм забезпечення прав пацієнтів психіатричних закладів, усуваючи при цьому прогалини та колізії з адміністративним законодавством та законами щодо охорони здоров’я.

\section{Список використаних джерел:}

1. Організація служб охорони психічного здоров'я: клінічна настанова, заснована на доказах, 2017. URL: https://cutt.ly/Og8zs18.

2. Казмірчук А.П., Іванцова Г.В., Льовків І.М. Організація надання медичної допомоги військовослужбовцям з психічними розладами під час антитерористичної операції на Сході України. Військова медищина України, 2017. № 1. C. $18-23$.

3. М'ю Клайв, Гнатовський М. Забезпечення належної якості лікування та догляду за пацієнтами в закладах охорони психічного здоров’я в Україні: порадник для спеціалістів, що базується на стандартах прав людини. Київ : «К.І.С.», $2019.75 \mathrm{c}$.

4. Про схвалення Концепції розвитку охорони психічного здоров'я в Україні на період до 2030 року : Розпорядження Кабінету Міністрів України від 27.12.2017 № 1018-р. Офіиійний вісник Украӥни. 2018. № 16. С. 65.

5. Стулов О.О. Проблеми забезпечення законності при наданні психіатричної допомоги засудженим до позбавлення волі. Держава та регіони, 2013. № 3. С. 97-100.

6. Чернушенко Д.А. Стандарти $\mathrm{OOH}$ щодо забезпечення прав користувачів психіатричної допомоги. Науковий вісник Національної академії внутрішніх справ, 2013. № 3. С. 173-181.

7. University of Kent. Mapping \& understanding exclusion in Europe. URL: https://cutt.ly/Gg81H9g.

\section{References:}

1. Asotsiatsiia psykhiatriv Ukrainy. Orhanizatsiia sluzhb okhorony psykhichnoho zdorovia klinichna nastanova, zasnovana na dokazakh [Organization of mental health services clinical evidence-based guidelines], 2017. Retrieved from: https://cutt.ly/Og8zs18 [in Ukrainian].

2. Kazmirchuk,A.P., Ivantsova,H.V.,Lovkiv,I.M.(2017). Orhanizatsiianadannia medychnoi dopomohy viiskovosluzhbovtsiam z psykhichnymy rozladamy pid chas antyterorystychnoi operatsii na Skhodi Ukrainy [Organization of medical care for 
servicemen with mental disorders during the anti-terrorist operation in Eastern Ukraine]. Viiskova medytsyna Ukrainy. No. 1. Pp. 18-23 [in Ukrainian].

3. Miu, Klaiv, Hnatovskyi, M. (2019). Zabezpechennia nalezhnoi yakosti likuvannia ta dohliadu za patsiientamy v zakladakh okhorony psykhichnoho zdorovia v Ukraini [Ensuring the proper quality of treatment and care for patients in mental health facilities in Ukraine]: poradnyk dlia spetsialistiv, shcho bazuietsia na standartakh prav liudyny. Kyiv: "K.I.S.”. 75 p. [in Ukrainian].

4. Pro skhvalennia Kontseptsii rozvytku okhorony psykhichnoho zdorovia v Ukraini na period do 2030 roku [About approval of the Concept of development of mental health care in Ukraine for the period till 2030]: Rozporiadzhennia Kabinetu Ministriv Ukrainy vid 27.12.2017 No.1018-r. Ofitsiinyi visnyk Ukrainy. 2018. No. 16. P. 65 [in Ukrainian].

5. Stulov, O.O. (2013). Problemy zabezpechennia zakonnosti pry nadanni psykhiatrychnoi dopomohy zasudzhenym do pozbavlennia voli [Problems of ensuring legality in the provision of psychiatric care to convicts]. Derzhava ta rehiony. No. 3. Pp. 97-100 [in Ukrainian].

6. Chernushenko, D.A. (2013). Standarty OON shchodo zabezpechennia prav korystuvachiv psykhiatrychnoi dopomohy [UN standards for ensuring the rights of psychiatric care users]. Naukovyi visnyk Natsionalnoi akademii vnutrishnikh sprav. No. 3. Pp. 173-181 [in Ukrainian].

7. University of Kent. Mapping \& understanding exclusion in Europe. Retrieved from: https://cutt.ly/Gg81H9g.

DOI https://doi.org/10.51647/kelm.2020.5.1.35

\title{
ZASADY PRAWA PODATKOWEGO I ICH ROLA W REGULACJI STOSUNKÓW UMOWNYCH W ZAKRESIE OPODATKOWANIA
}

\author{
Ihor Herashchenko \\ student Katedry Prawa Administracyjnego i Celnego \\ Uniwersytetu Sprawy Celnej i Finansów (Dniepr, Ukraina) \\ ORCID ID: 0000-0003-0694-8479 \\ Herashchenko@gmail.com
}

Adnotacja. Artykuł poświęcony jest kompleksowej analizie zasad prawa podatkowego i ich roli w regulacji stosunków umownych w zakresie opodatkowania. Zasady prawa wyrażaja podstawowe idee, postulaty, określajace treść i ukierunkowanie prawa. Ponadto zasady prawa stanowią podstawę systemu prawa jako całości, w wyniku czego działają jako regulator public relations.

Wyjaśniono, że przez zasady prawa należy rozumieć początkowe punkty, które rozwinęły się w prawie na pewnym etapie historycznym pod wpływem obiektywnych czynników, regulujących stosunki społeczne i mających na celu połączenie grupowych i indywidualnych interesów społeczeństwa.

Podkreśla się, że system zasad prawa podatkowego został ustalony w art. 4 Kodeksu Podatkowego Ukrainy.

Stwierdzono, że do wyraźnie określonych zasad prawa podatkowego, które wpływaja na regulację stosunków umownych w zakresie opodatkowania należą: 1) Zasada powszechności opodatkowania (ppkt 4.1.1 pkt 4.1 art. 4 Kodeksu Podatkowego Ukrainy); 2) zasada równości wszystkich płatników podatków (zasada niedyskryminacji) (ppkt 4.1 .2 pkt 4.1 art. 4 Kodeksu Podatkowego Ukrainy).

Słowa kluczowe: zasada prawa, zasada powszechności opodatkowania, zasada równości wszystkich płatników podatków (zasada niedyskryminacji), równość, akty prawne.

\section{PRINCIPLES OF TAX LEGISLATION AND THEIR ROLE IN REGULATING CONTRACTUAL RELATIONS IN THE FIELD OF TAXATION}

\author{
Ihor Herashchenko \\ Applicant at the Department of Administrative and Customs Law \\ University of Customs and Finance (Dnipro, Ukraine) \\ ORCID ID: 0000-0003-0694-8479 \\ Herashchenko@gmail.com
}

\begin{abstract}
The article is devoted to a comprehensive analysis of the principles of tax legislation and their role in regulating contractual relations in the field of taxation. The principles of law express the basic ideas, postulates that determine the content and direction of law. In addition, the principles of law form the basis of the legal system as a whole, and as a consequence act as a regulator of social relations.

It was found that the principles of law should be understood as the starting principles that have developed in law at a certain historical stage under the influence of objective factors that regulate social relations and aim to combine group and individual interests of society.
\end{abstract}

